\title{
OBRAS DE DOREEN MASSEY
}

Spatial Divisions of Labor: social structures and the geographies of production. Nova York: Routledge, 1995 (1984)

1. The Issues

2. Social Relations and Spatial Organisation

3. Uneven Development and Spatial Structures

4. Some Changing Spatial Structures in the United Kingdom

5. The Effects of Local Areas: Class and Gender Relations

6. Class, Politics and the Geography of Emplyment

7. The Reproduction of Inequality: A Questiono of Politics

Primeira grande obra de Doreen Massey, numa abordagem marxista renovada, este livro provocou vivo debate, antecipando questões que somente um tempo depois seriam devidamente consideradas. A própria autora, no prefácio à segunda edição, destaca que sua formulação esteve ligada às grandes mudanças econômicas e socioespaciais em curso, a partir da metade dos anos 1960, especialmente no nível regional (que ela, genericamente, associa com o nível "subnacional"). A questão do desenvolvimento espacialmente desigual é aprofundada a partir da realidade anglo-saxônica e, de modo inovador, a divisão do trabalho é tratada também na sua dimensão de gênero. $\mathrm{Na}$ segunda edição, publicada onze anos após a primeira, são acrescentados dois capítulos - o primeiro e o último no sumário acima reproduzido.
Space, Place and Gender. Minneapolis: University of Minnesota Press, 1994.

Part I. Space and Social Relations

Part 2. Place and Identity

Part 3. Space, Place and Gender

Nesta importante contribuição ao pensamento geográfico de seu tempo, Doreen Massey trabalha uma relação até então pouco aprofundada na Geografia: a relação entre espaço e gênero. Além disso, problematiza abordagens teórico-conceituais de outros geógrafos, como faz com David Harvey e Edward Soja no texto intitulado Flexible Sexism. O livro é na verdade a reunião de artigos distintos, publicados em diferentes veículos no período entre 1978 ("Industrial restructuring versus the cities") e 1992 ("Politics and Space/Time"). Seu capítulo mais conhecido, divulgado através de várias outras publicações, é $O$ sentido global de lugar, onde apresenta sua famosa concepção de lugar como espaço aberto, conexão de múltiplas redes, e onde a diferença decorre da especificidade dessas combinações muito mais do que da natureza dos fenômenos em si mesmos (artigo publicado em português em Arantes, A. 2000. 0 espaço da diferença. Campinas: Papirus, disponível em http://www2.fct.unesp.br/docentes/geo/necio_turra/ PPGG \% 20-\%20PESQUISA\%20QUALI\%20PARA\%20 GEOGRAFIA/O\%20ESPAC0\%20DA\%20DIFERENCA $\% 20$ $-\% 20$ Arantes.pdf) 
For Space. Londres: Sage, 2005 / Pelo Espaço: uma nova política da espacialidade. Rio de Janeiro: Bertrand Brasil, 2008

\section{Parte I. Estabelecendo o cenário}

Parte 2. Associações pouco promissoras

Parte 3. Vivendo em tempos espaciais?

Parte 4. Reorientações

Parte 5. Uma política relacional do espacial

Segundo a própria autora, "o argumento fundamental deste livro é que importa o modo como pensamos o espaço; o espaço é uma dimensão implícita que molda nossas cosmologias estruturantes. Ele modula nossos entendimentos do mundo, nossa atitudes frente aos outros, nossa política. Afeta o modo como entendemos a globalização, como abordamos as cidades e desenvolvemos e praticamos um sentido de lugar. Se o tempo é a dimensão da mudança, então o espaço é a dimensão do social: da coexistência contemporânea de outros. E isso é ao mesmo tempo um prazer e um desafio". Trata-se da principal obra teórica da autora, onde desenvolve sua tese do espaço como imbricação de trajetórias, sempre em aberto, dotado, portanto, de um grau de contingência e "eventualidade", concepção que tem claras consequências políticas, demonstrando o quanto a autora defende a indissociabilidade entre construção teórico-conceitual e ação política.
World City. Cambridge: Polity, 2007.

Introduction: "the future of our world"?

Part I. Inventing a world city

Part II. The world in the country

Part III: The world city in the world

Concluding Reflections

Em seu último livro individual, Doreen Massey se volta para sua cidade, Londres, vista como Cidade Mundial ou Global. Aqui ela aciona seu conceito de lugar como uma "constelação" identitária que problematiza o dentro e o fora, como espaço aberto mais do que delimitado, receptivo mais do que exclusivo-excludente e sempre em mutação. A partir daí ela trabalha questões como a que defende a possibilidade de "pensar a identidade dono lugar [placed identity] não como uma reivindicação por um lugar mas como o reconhecimento da responsabilidade inerente ao estar em um lugar [being placed]". 